\title{
Mulheres, saúde e grupalidade: estudo do grupo de Convivência Reviver, Botucatu, SP
}

\author{
Women, health and group: study of Reviver social group, Botucatu, SP \\ Mujeres, salud y grupo: estudio de grupo de convivencia Reviver, Botucatu, SP
}

As atividades grupais estão presentes em várias áreas do conhecimento e têm sido uma importante ferramenta na Atenção Primária à Saúde. Quando entendido como processo, o grupo pode representar a resistência aos modos individualizantes, pode atuar como um dispositivo capaz de construir modos de subjetividade singulares. O presente trabalho descreveu e analisou a experiência de um grupo de vivência de mulheres enquanto espaço de produção de desejos, desmistificando modos de ser e de viver. $A$ investigação, de natureza qualitativa, foi conduzida com as integrantes do grupo de convivência Reviver, constituído por senhoras na faixa dos 50 anos ou mais. O grupo começou em 1999, tendo como público-alvo usuárias da área de saúde mental do Centro de Saúde Escola (CSE), da Faculdade de Medicina de Botucatu da Universidade Estadual Paulista (UNESP); e, como proposta, ser um espaço de promoção da saúde e de lazer. Inicialmente, eram encaminhadas pelo CSE, mas, com o fortalecimento do grupo, as próprias participantes começaram, também, a convidar amigas e familiares. As técnicas de coleta utilizadas foram: observação participante, entrevista com formuladores do grupo, e entrevistas baseadas nas histórias de vida de cinco mulheres. As histórias de vida foram transcritas e estudadas mediante análise temática de conteúdo. Os núcleos temáticos foram identificados segundo os diferentes ciclos da vida, tendo como mais relevantes: na infância e juventude (as dificuldades financeiras e a violência) e na vida de casada ("o lugar de mulher é dentro de casa", laços sociais fragilizados, dificuldades financeiras, experiências de violência e a ajuda profissional). Reconheceram-se, ainda, os núcleos temáticos significativos relativos à vivência do grupo Reviver, quais sejam: as experiências que levaram ao grupo, "ser bem recebida", "estar junto", a solidariedade, o "lidar melhor com o sofrimento mental", o "medo de ficar sem o grupo" e o "experimentar o novo". As narrativas mostraram quanto o fato de ser mulher, em determinado contexto social, limitou-as em relação às suas escolhas pessoais. Essas mulheres ficaram isoladas no ambiente familiar, dedicando-se às tarefas domésticas ou ao trabalho até que os filhos estivessem crescidos. Entretanto, o que se pôde constatar, depois que começaram a frequentar o Reviver, foi uma transformação em suas vidas. Isso pode ter ocorrido porque o grupo operou como um dispositivo, produzindo novas possibilidades de experimentação. Ao fazer funcioná-las, o grupo rompeu com formas enrijecidas de ser e viver, de mulheres silenciadas e homogeneizadas. Elas encontraram um local onde puderam participar de atividades culturais e de lazer diversas (passeios, festa de carnaval, Dia das Mães etc.). Um espaço em que elas puderam desenvolver a criatividade, vivendo situações novas e desafiadoras: ser artista de teatro, dançar, publicar um livro, passear com amigas, resgatar a alegria e o prazer de viver com o outro. Não serem apenas expectadoras, mas, sim, subirem ao palco e serem protagonistas de suas próprias vidas. No grupo, elas experimentaram outros modos de subjetividade que contribuíram para desmanchar territórios cristalizados.

Andrea Langbecker Dissertação (Mestrado), 2010. Programa de Pós-Graduação em Saúde Coletiva, Faculdade de Medicina de Botucatu, Universidade Estadual Paulista. alangbecker@hotmail.com

\footnotetext{
Palavras-chave: Processo grupal. Grupo dispositivo. Histórias de vida. Saúde. Keywords: Group process. Group device. Stories of life. Health. Palabras clave: Grupo de procesos. Grupo de dispositivos. Historias de vida. Salud.
} 